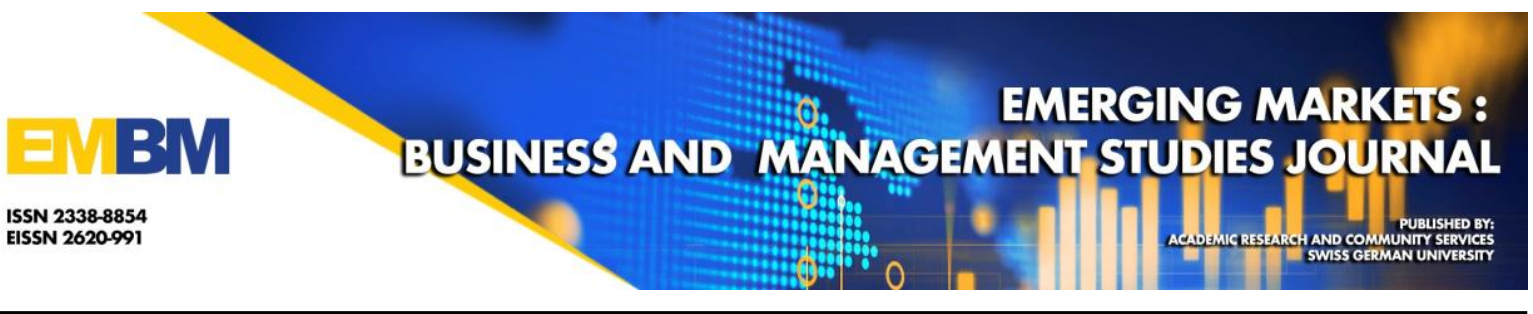

\title{
IMPLEMENTASI DIGITAL MARKETING PT. TAMAN WISATA CANDI SELAMA PANDEMIK COVID-19
}

\author{
Tsanaa Khenresta, Yonaz Salasa, Rani Chandra Oktaviani
}

Program Pascasarjana Ilmu Komunikasi Institut Komunikasi dan Bisnis LSPR, Jakarta, Indonesia

Article Information

Received: 25 August 2021

Accepted: 8 October 2021

Published: 15 October 2021

DOI: $10.33555 / \mathrm{embm} . v 9 \mathrm{i} 1.191$

Corresponding Author:

Tsanaa Khenresta

Jakarta, Indonesia

Email: 20210330085@1spr.edu

ISSN 2338-8854

eISSN 2620-9918

\begin{abstract}
ABSTRAK
Penelitian ini membahas tentang bagaimana implementasi strategi komunikasi pemasaran PT. TWC di media digital selama pandemic COVID-19. Penelitian ini memiliki tujuan untuk memahami strategi komunikasi pemasaran PT. TWC di media digital dan memahami taktik dan alternatif promo PT. TWC selama masa pandemi COVID-19. Penelitian dilakukan secara deskriptif kualitatif dengan melakukan wawancara kepada informan internal dan informan ahli. Selain itu, dilakukan kajian pustaka dan observasi. Penelitian ini memperlihatkan bahwa PT. TWC meunju proses digitalisasi dalam memasarkan produk. Selain itu, PT. TWC juga menggunakan virtual tur sebagai taktik alternatif strategi komunikasi pemasaran.
\end{abstract}

Kata kunci: Media Sosial, Pandemi COVID-19, Strategi Komunikasi Pemasaran, Virtual Tur

\section{ABSTRACT}

This study discusses how the implementation of the marketing communication strategy of PT. TWC on social media during the COVID-19 pandemic. This study aims to understand the marketing communication strategy of PT. TWC on social media and understand the tactics and alternative promos of PT. TWC during the COVID-19 pandemic. The research was conducted in a qualitative descriptive manner by conducting interviews with internal informants, external informants, and expert informants. In addition, literature review and observations were carried out. This study shows that there is a digitalization trend carried out by PT. TWC. In addition, PT. TWC is also using virtual tours as an alternative tactic to its marketing communication strategy

Keywords: COVID-19 Pandemic, Marketing Communication Strategy, Social Media, Virtual Tour 


\section{Pendahuluan}

Corona Virus termasuk dalam keluarga Coronaviridae dalam ordo Nidovirales (Shereen, dkk, 2020, hal. 2). Virus ini awalnya hanya dapat menginfeksi hewan sampai akhirnya satu decade kemudian, virus ini berkembang menjadi MERS-CoV, dan menjadi endemic di negara Timur Tengah. Pada akhir 2019, virus ini menginfeksi manusia, dan terjadi wabah virus Corona di Wuhan, China. Dalam lima puluh hari pertama epidemi, virus ini telah menginfeksi lebih dari tujuh puluh ribu orang. Virus baru ini akhirnya diberi nama 2019-nCov atau Novel Corona Virus oleh para peneliti di China atau disingkat COVID-19 (Shereen et al., 2020). Tidak sampai di situ, karena persebaran virus yang begitu cepat, membuat COVID-19 tersebar di seluruh negara, dan menjadikan COVID19 sebagai pandemi. Virus ini ditularkan melalui sebuah droplets, sehingga membuat kita harus saling jaga jarak satu sama lain, memakai masker, dan mencuci tangan. Adanya pandemic ini membuat setiap orang memiliki ruang gerak yang sangat terbatas. Seperti diketahui, kita tidak boleh menghadiri kerumunan, karena virus sangat mudah menyebar \& menular. Tentu pandemic ini membuat seluruh dunia lumpuh di segala bidang. Terutama di bidang pariwisata, fenomena ini tidak hanya terjadi di Indonesia, namun di seluruh dunia.

Adanya COVID-19 membuat pemerintah menerapkan PSBB (Pembatasan Sosial Berskala Besar) di beberapa wilayah di Indonesia. Hal ini lah yang merupakan salah satu penyebab anjloknya pariwisata di Indonesia. Menurut Badan Pusat Statistik dalam Berita Ekonomi, pertumbuhan ekonomi nasional kuarta II tahun 2020 mengalami titik terendah sejak 1999, yaitu di angka 5.32\% (Fauzan, 2020). Penurunan jumlah kegiatan wisata juga terlihat di beberapa kota besar seperti Bali, Jawa Barat, dan Kepulauan Riau.
Menurut data Badan Pusat Statistik, tujuan tempat wisata di Indonesia dapat dibagi menjadi enam berdasarkan jenis objek daya tarik wisata seperti terlihat pada Gambar 1.

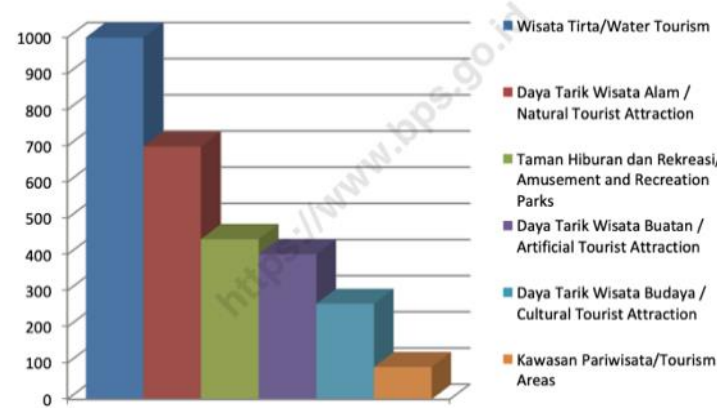

Gambar 1. Grafik jenis objek daya tarik wisata di Indonesia per 2018

(Sumber: Badan Pusat Statistik)

Jika dilihat pada Gambar 1, wisata budaya mendapatkan poin kedua terkecil dari enam tujuan tempat wisata. Penelitian ini akan mengklasifikasikan keenam objek wisata tersebut menjadi dua, yaitu wisata budaya dan wisata non budaya. Taman wisata budaya merupakan tempat budaya yang dilestarikan, seperti Candi Borobudur, permukiman desa, dan sebagainya (Pujiyati et al., 2017). Wisata budaya juga mencakup wisata cagar budaya. Pengembangan wisata cagar budaya sudah dilakukan sejak lama. Pariwisata budaya juga dapat melestarikan objek wisata budaya tersebut namun dapat merusaknya karena adanya kegiatan pariwisata, jika tidak mementingkan aspek lingkungannya. Sisi positif penembangan cagar budaya menjadi tempat wisata adalah, dapat mengembangkan perekonomian warga lokal di sekitara cagar budaya (Syamyanti, 2018; Butler, 1991; Goodal, 1997).

Tidak seperti objek wisata pada umumnya, objek wisata budaya bertujuan untuk mengedukasi pengunjung dengan menghadirkan pengetahuan pada masa lalu. Sehingga pengelola situs objek wisata budaya harus membuat penyesuaian agar pesan yang ingin disampaikan sampai dengan baik di pengunjung. Hal ini merupa- 
kan tantangan terhadap pengelola situs objek wisata untuk tetap melestarikan budaya dalam wisata budaya bersamaan memeberikan hiburan yang menarik (Farrisee, 1999 dan Li, 2003).

Objek wisata budaya salah satunya ialah peninggalan sejarah. Peninggalan sejarah adalah bangunan yang dibangun pada zaman dahulu, seperti masjid, makam petilasan, prasasti, dan candi. Candi merupakan salah satu peninggalan sejarah yang dapat ditemui di Indonesia. Candi merupakan salah satu wisata budaya yang memiliki arti bangun suci sebagai sisa sarana ritual agama Hindu dan Buddha. Di Indonesia, bangunan suci ini dikenal dengan nama Candi, sementara di luar Indonesia memiliki penamaan yang berbeda, Köil di India Selatan, prasat di Kamboja, serapan dari kata prasada (Sedyawati et al., 2013). Candi banyak ditemukan di Asia, terutama negara-negara yang merupakan negara pesebaran agama Hindu dan Buddha, seperti India, Indonesia, Thailand, dan Kamboja.

PT. Taman Wisata Candi - selanjutnya ditulis PT. TWC. PT. TWC menaungi tiga candi yang tersebar di sekitaran Jogja Jawa Tengah. Ketiga candi tersebut ialah Candi Borobudur, Candi Prambanan, dan situs Candi Ratu Boko. Dalam segi pengelolaan pariwisata candi, pihak pemerintah dibantu oleh PT. TWC dan untuk pemeliharaan candi / ring 1 cagar budaya langsung dibawah pengelolaan Kementerian Pendidikan dan Kebudayaan. Baik pemenrintah pusat dan PT. PWC bahu-membahu untuk mengoptimalkan tempat wisata berbasis peninggalan sejarah ini supaya memiliki manfaat bagi banyak pihak.

Semenjak pandemi, PT. TWC melaporkan penurunan wisata pada ketiga tempat objek wisata tersebut mencapai angka $40.8 \%$ dari sebelumnya. Hal ini dilaporkan oleh Edy Setijono selaku direktur utama PT. TWC. Selama COVID-19, ketiga tempat objek wisata sempat tutup dan sampai sekarang pengunjung hanya boleh berwisata di pelataran candi saja, berlaku di semua Candi yang dinaungi PT. TWC. Aturan baru tersebut mendukung upaya pemerintah untuk menekan angka persebaran virus COVID-19. Hampir satu tahun pandemi berlangsung di Indonesia, Kementerian Pariwisata pun akhirnya membuatkan standar baru untuk tempat wisata yang berlandaskan pada Keputusan Mentri Kesehatan tentang Protokol Kesehatan bagi masyarakat di tempat dan fasilitas umum dalam rangka pencegahan dan pengendalian virus COVID-19. Sertifikasi CHSE (Clean, Health, Safety Environment) yang menjamin tempat tujuan wisata memiliki standar kebersihan, kesehatan, dan keselamatan, serta kelestarian lingkungan. PT. TWC sudah mendapatkan sertifikasi CHSE untuk ketiga objek wisatanya, sehingga wisnus maupun wisman bisa berwisata dengan aman dan tenang. Dengan adanya sertifikasi ini, diharapkan pengunjung dapat datang berkunjung kemabali ke tiga objek wisata naungan PT. TWC. Tentu tidak lupa dengan penerapan protokol kesehatan nya. Perubahan aturan yang diberlakukan pemerintah membuat masyarakat tidak bisa berwisata secara langsung. Hal ini membuat PT. TWC gencar melakukan kegiatan melalui media sosial. Promosi yang biasanya dilakukan melalui offline, kini sudah berubah menjadi promosi online yang dilakukan pada laman resmi webisite dan juga media sosial PT. TWC. Berubahnya tren dan digitalisasi membuat PT. TWC harus mencari cara yang paling efektif dalam melakukan promosi online di kala masa pendemi COVID-19.

Menurut data APJII 2019, penetrasi pengguna internet bertambah sebesar $8.9 \%$ dari tahun sebelumnya. Pada tahun 2018, penetrasi pengguna internet di Indonesia berada di angka $64.8 \%$. Sementara itu, alasan pertama mengapa seseorang menggunakan internet adalah penggunaan media sosial. Dengan demikian, promosi 
yang dilakukan secara online melalui media sosial merupakan salah satu cara efektif untuk memasarkan objek wisata PT. TWC. Masing-masing objek wisata PT. TWC hadir di empat platform media sosial, yaitu Twitter, Instagram, Youtube, dan Facebook. Masing-masing objek wisata memiliki akun medianya sendiri-sendiri. Selain media sosial, PT. TWC juga menggunakan website resmi sebagai salah satu platform penyaluran informasi.

Keadaan yang sangat berubah secara signifikan membuat PT. TWC harus beradaptasi dengan cepat. Pandemi ini merupakan hal baru yang akan berdampak pada bagaimana PT. TWC mempromosikan ketiga objek wisata ini. Permasalahan penelitian ini difokuskan kepada bagaimana implementasi digital marketing PT. TWC selama masa pandemik COVID-19. Penelitian ini memiliki tujuan untuk memahami strategi komunikasi pemasaran PT. TWC di media digital selama pandemik COVID-19, untuk memahami taktik dan alternatif promosi PT. TWC di media digital pada masa pandemik COVID-19, dan mengetahui kelemahan dan kelebihan PT. TWC dalam implementasi strategi komunikasi pemasaran di media digital pada masa pandemik COVID-19. Penelitian ini terbatasan hanya meneliti ketiga objek wisata budaya yang dinaungi PT. TWC (Candi Borobudur, Candi Prambanan, dan Ratu Boko) dan media social yang dikelola oleh tim Digital, PR, dan Media Officer PT. TWC.

\section{Tinjauan Literatur}

Penelitian yang terbit pada tahun 2015 membahas bagaimana implementasi PT. TWC dalam meningkatkan jumlah pengunjung \& laba perusahaan. Penelitian ini dilakukan secara kualitatif deskriptif (Yulianto, 2015). Hasil penelitian ini memperlihatkan bahwa implementasi strategi yang digunakan oleh PT. TWC adalah strategi pemasaran low cost high impact pada tahun 2014. Dengan ini PT. TWC dapat meningkatkan pengunjung sebanyak $2.8 \%$ dan $10.4 \%$ keuntungan dari tahun sebeulumnya. Namun strategi ini belum memberikan hasil terbaiknya, Dikarenakan kenaikan biaya operasional yang juga lebih bayak dibandingkan laba yang diterima oleh perusahaan (Yulianto, 2015).

Penelitian berikutnya ditulis oleh Junaidi Pranata. Penulis ingin mengetahui strategi komunikasi pemasaran yang dilakukan Dinas Kebudayaan dan Pariwisata Kabupaten Karo pada objek wisata Gundaling dan Pemandian Air Panas Semangat Gunung. Melihat dari segi fenomenologi, tempat wisata ini memiliki daya tarik yang tidak terbatas, antara lain bentang alam dan juga budayanya (Sembiring, 2016). Hasil penelitian ini memperlihatkan bahwa strategi komunikasi pemasaran yang dilakukan oleh pihak Dinas Kebudayaan dan Pariwisata Kabupaten Karo adalah menggunakan IMC tools dalam bentuk iklan, humas, promosi penjualan, dan penjualan langsung dalam bentuk yang informatif, persuasive, juga edukatif. Faktor pendukung tempat wisata ini adalah bentang alam yang indah sehingga banyaknya wisatawan yang datang sehingga dapat 'menghidupi' masyarakat lokal, akses menuju tempat wisata juga terbilang murah dan mudah, 1,5 jam dari Medan. Di sisi lain, faktor penghambatnya ialah kurangnya kordinasi antara Dinas Kebudayaan dan Pariwisata Kabupaten Karo dan pelaku wisata di tempat objek wisata, walaupun memiliki bentang alam yang indah, lingkungan kurang terawatt dan juga fasilitas umum yang kurang memadai. Tentu kedua hal ini merupakan 'PR' untuk Pemerintah Daerah Karo supaya tempat wisata ini tidak tertinggal oleh tempat wisata lainnya (Sembiring, 2016).

Chaffey, D., dan Ellis-Chadwick (2016) mendefinisikan digital marketing sebagai melakukan pemasaran dengan mengkombinasikannya dengan teknologi dan media digital. Sementara Clow dan Baack (2018) 
memaparkan bahwa digital marketing merupakan kombinasi antara semua kompenen yang berada di internet, dari $e$ commerce, marketing internet, juga mobile marketing, digital marketing merupakan kegiatan pemasaran yang dilakukan di platform digital.

Chaffey, D., dan Ellis-Chadwick (2016) membagi tiga tujuan digital marketing:

\section{Identifying}

Internet sebagai wadah tempat pencarian informasi apa yang dibutuhkan dan diperlukan calon pembeli.

\section{Anticipating}

Internet sebagai wadah yang memudahkan pelanggan untuk mengakses informasi dan juga melakukan pembelian.

\section{Satisfying}

Faktor utama keberhasilan digital marketing adalah mencapai kepuasan pelanggan. Salah satu faktornya adalah, apakah fitur tersebut mudah digunakan? Bagaimana kinerja web tersebut?

Ketiga tujuan tersebut dapat diwujudkan dengan cara penerapan strategi digital marketing. Para praktiknya, digital marketing mengemas sebuah produk menjadi sesuatu yang bersifat online. Seperti website dan media sosial yang dapat diakses melalui berbagai bentuk teknologi seperti gawai dan juga laptop (Chaffey dan Ellis-Chadwick, 2016).

\section{Metode Penelitian}

Penelitian ini merupakan penelitian deskriptif kualitatif. Menggunakan paradigma konstruktivisme dengan tradisi fenomenologi. Paradigma Konstruktivisme merupakan pelengkapan epistemologis, paradigma konstruktivisme melihat fenomena realita sebagai produk dan penciptaan manusia (Hanitzsch, 2001). Penelitian ini dilakuan dengan cara cara mewawancara, studi pustaka, dan juga observasi. Wawancara dilakukan dengan tim dari Digital, PR, dan Media Officer PT. TWC. Penelitian ini juga melakukan triangulasi data dengan cara melakukan observasi di media social dan juga melakukan wawancara dengan Ahli di bidang pariwisata dan komunikasi pemasaran.

Tabel 1. Fokus Penelitian

\begin{tabular}{lll}
\hline Objek & Elemen & Keterangan \\
Penelitian & & \\
\hline $\begin{array}{l}\text { Implementasi } \\
\text { Digital } \\
\text { Marketing }\end{array}$ & Identifying & $\begin{array}{l}\text { Wawancara \& } \\
\text { observasi di } \\
\text { media sosial }\end{array}$ \\
\cline { 2 - 2 } & Anticipating & \\
\cline { 2 - 2 } & Satisfying & \\
\hline
\end{tabular}

\section{Hasil dan Diskusi}

Dewasa ini, internet merupakan salah satu hal yang tidak dapat dipisahkan oleh manusia. Seiring berkembangnya dunia teknologi, banyak juga platform baru yang bermuculan seperti TikTok. Hal ini membuat pelaku bisnis harus terus beradaptasi. Pada penelitian ini, walaupun objek wisata yang dipromosikan adalah objek wisata budaya, terlebih lagi merupakan objek wisata purbakala yang memiliki histori yang sangat kaya dan nilai magis bagi yang mempercayaiinya. PT. TWC selaku pengelola harus dapat mengemas ketiga objek wisata ini secara modern.

Penggunaan media digital untuk melakukan kegiatan promosi yang dilakukan oleh PT. TWC sebenarnya sudah dilakukan sejak lama, tidak baru dilakukan saat pandemik. PT. TWC menggunakan beberapa aspek digital marketing seperti social media marketing, SEO, Online Partnership, dan interactive advertising. PT. TWC mengemas semua informasi ataupun kegiatan melalui media sosial \& web yang mereka punya dan platform ini saling berkaitan satu sama lain. Hal ini sangat memudahkan para calon konsumen dalam mencari informasi terkait. Dalam hal ini, penggunaan website dan juga media sosial 
oleh PT. TWC tidak hanya bertujuan untuk promosi saja. Menurut Ruri (2021), "kegiatan promosi yang dilakukan secara offline dan juga online, sekarang jadi berubah menjadi online semua Mba (Prasasti Ruri Agastya, wawancara data primer, 8 Juli 2021).”

Saat dilakukannya observasi pada media social yang dikelola oleh PT. TWC, implementasi kegiatan promosi juga gencar dilakukan. Terutama mempromosikan sertifikasi CHSE, protocol Kesehatan, informasi seputar COVID-19, dan info mengenai vaksinasi.

Selama pandemik COVID-19 pun PT. TWC mengawali program baru, yaitu virtual tour. Berkolaborasi dengan Balai Konservasi Borobudur, PT. TWC membuat Virtual Tour berjudul Menguak Rahasia Hidup Sehat dari Relief Candi Borobudur?. Virtual tour ini dilakukan di Zoom dengan 201 peserta, lalu dibagikan kembali di YouTube, dan memiliki 1518 views.

"virtual tour yang kami lakukan mendapatkan response yang sangat bagus. Kami juga melakukan kerja sama dengan beberapa media partner untuk memasarkan terkait acara ini (Bara Okta Pratista Johannanda, wawancara data primer, 8 Juli 2021)".

Di masa pandemic ini, virtual tour merupakan salah satu alternatif untuk para pelaku wisata memasarkan produknya. Virtual tour merupakan salah satu cara dimana wisatawan dapat menikmati keindahan tempat wisata tanpa harus datang ke tempat wisata tersebut. Dapat diakses melalui foto maupun video. Bentuk virtual tour berbagi dalam beberapa macam antara lain, foto, video, virtual reality photography, video $360^{\circ}$, interactive video $360^{\circ}$, dan virtual reality. Penerapan virtual tour tentu tidak lepas dari teknologi yang sudah sangat berkembang saat ini (Muhammad, 2021). Virtual tour diharapkan dapat memanjakan para wisatawan yang tidak dapat berkun- jung saat masa PPKM ini. Penggunaan media sosial dan media digital yang sangat up-to-date juga memperlihatkan keseriusan PT. TWC untuk melakukan promosi secara digital. Penerapan dgitial marketing yang dilakukan PT. TWC yaitu social media marketing, online partnership, dan interactive advertising sudah dapat memudakan para calon wisatawan dalam mengakses informasi mengenai ketiga objek wisata tersebut. Selian itu, calon wisatawan juga dapat melakukan pembelian tiket langsung di website PT. TWC.

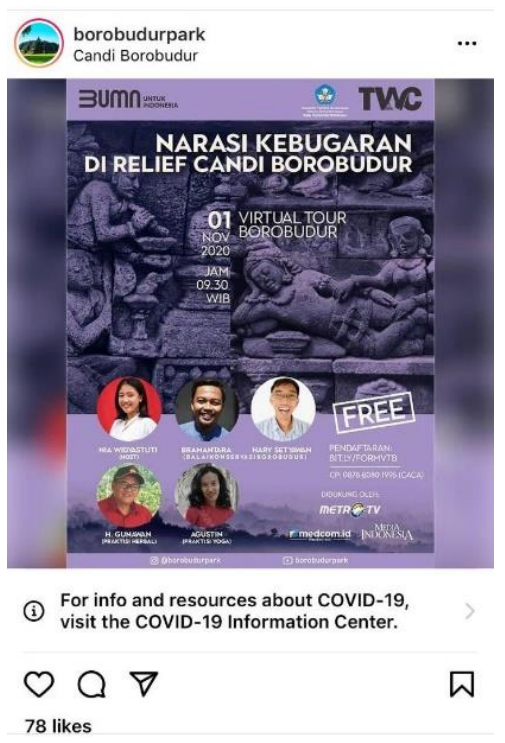

Gambar 2. Poster Promosi Virtual Tour (Sumber: Instagram @borobudurpark).

Sebagai penyedia jasa dan layanan, PT. TWC memberikan keempat point experience of economy yaitu entertainment, education, esthetics, dan escapism. Entertainment dapat berupa atraksi hiburan seperti kegiatan menaiki gajah juga sendratari rama sinta. Education, PT. TWC

Berkolaborasi bersama Balai Konservasi Borobudur untuk menghadirkan informasi terkait Candi Bodobudur. Setelah dilakukannya pemugaran, keindahan yang ditawarkan oleh ketiga objek wisata masih tetap sama. Walaupun usia candi tidak muda lagi. Setelah dilakukannya observasi pada media social dan media digital, kegiatan virtual tour dapat memenuhi point 
education dan esthetics yang dapat dikemas secara online. Pun hanya dapat diakses melalui layar handphone maupun laptop, tidak dapat merasakan keindahannya secara langsung. Kedua objek lainnya sedikit lebih susah dihadirkan dalam bentuk online, yaitu entertainment dan escapism.

Pada tahap identifying, PT. TWC melakukan digital marketing karena perkembangan teknologi sehingga pemasaran yang dilakukan channel pemasaran memiliki perluasan, melalui media digital. Melihat kebiasaan perubahanan tren target market (wisatawan) yang mengandalkan internet sebagai sumber informasi. Selama pandemik, PT. TWC mengkampanyekan secara massif tentang CHSE. Dengan tujuan untuk memberikan awareness tentang berwisata aman candi selama masa pandemik COVID-19. Dengan terbatasnya ruang gerak para calon wisatawan, PT. TWC mengahdirkan virtual tour sebagai bentuk anticipating. Virtual tour dilakukan dengan melakukan perjalanan di Candi Borobudur dan kegaiatan lain seperti yoga dan membuat jamu. Virtual tour ini dilakukan melalui platform zoom. Virtual tour ini mendapatkan respon yang sangat baik, sehingga virtual tour dibagikan kembali di Youtube, supaya dapat dinikmati berulang kali. Selain virtual tour, PT. TWC sedang membangun program yang tujuan quality visitor, yang mana diharapkan dari program ini setaip wisatawan yang datang mendapatkan informasi dan juga pengalaman yang tidak terlupakan. Program ini akan menintegrasi zona I, II, dan III. Pada tahap satisfaying, PT. TWC memudahkan para calon wisatawan, wisatawan dengan mudah mengakses YouTube dan bisa menonton kembali. mendapatkan respon yang positif terkait virtual tour ini. ga strategi komunikasi yang dilakukan.

Platform yang digunakan PT. TWC untuk mempromosikan ketiga objek wisata itu melalui media digital dan media sosial; website, Instagram, Facebook, Youtube, dan Twitter. Kelima platform tersebut juga saling terintegrasi satu sama lain, sehingga memudahkan para calon wisatawan untuk mendapatkan informasi.

\section{Kesimpulan}

Maka dapat disimpulkan bahwa, selama masa pandemik COVID-19, dalam penggunaan digital marketing PT. TWC mencapai ketiga tujuan yang disebutkan oleh Chaffey, D., dan Ellis-Chadwick yaitu identifying, anticipating, dan satisfying dan melalui ke-enam tahapan dalam menyusun strategi dalam pengimplementasiannya di media digital dan media sosial. Penelitian ini dilakukan dengan cara wawancara mendalam dengan dua narasumber internal dan satu narasumber ahli.

Dalam penerapan digital marketing, PT. TWC hadir dalam bentuk media digital dan media sosial. Tentu hal ini sudah cukup baik memberikan informasi terkait objek wisata yang dimiliki, namun, terlalu banyaknya media sosial yang juga mempromosikan ketiga objek tersebut. Menurut peneliti, akan lebih efektif dan efesien jika semua informasi dikumpulkan dalam satu akun yang sama, tidak terpisah-pisah.

\section{Daftar Pustaka}

APJII. (2019). Laporan survei internet APJII 2019-2020 [Q2]. Diakses dari https://apjii.or.id/survei

BPS. (2018). Statistik objek daya tarik wisata. Diakses dari https://www.bps. go.id/publication/2020/06/19/1f1c6cd 9713ae7fc8dd99534/statistik-objekdaya-tarik-wisata-2018.html

Butler, R. W. (1991). Tourism, environment, and sustainable development. Environmental Conservation, 18(3), pp. 201-209. https://doi.org/10.1017/S0376892900 022104 
Chaffey, D., \& Ellis-Chadwick, F. (2016). Digital marketing: strategy implementation and practice, $\left(6^{\text {th }}\right.$ ed.). Harlow: Pearson.

Clow, K. \& Baack, D. (2018). Integrated advertising, promotion, and marketing communications $\quad\left(8^{\text {th }}\right.$ Global ed.) Harlow: Pearson.

Farrisee, A. (1999). Heritage tourism: Telling the rest of the story. The Georgia Historical Quarterly, 83(1), pp. 101-107.

Fauzan, R. (2020, Agustus 7). Pandemi berdampak cukup besar bagi sektor pariwisata. Diakses pada 10 Januari 2021 pada: https://ekonomi.bisnis. com/read/20200807/12/1276123/pa ndemi-berdampak-cukup-besarbagi-sektor-pariwisata-

Goodall, B. (1997). The future for heritage tourism. Geographical Journal, 163(2), pp. 243-244.

Hanitzsch, T. (2001). Teori sistem sosial dan paradigma konstruktivisme: tantangan keilmuan jurnalistik di era informasi. Mediator: Jurnal Komunikasi, 2(2), pp. 217-229.

Li, Y. (2003). Heritage tourism: The contradictions between conservation and change. Tourism and Hospitality Research, 4(3), pp. 247-261.

Muhammad, R., Mutiarin, D., \& Damanik, J. (2021). Virtual tourism sebagai alternatif wisata saat pandemi. Journal of Indonesian Tourism, Hospitality and Recreation, 4(1), pp. 53-60.

PT. Taman Wisata Candi. Diakses pada 10 May 2020, dari http://borobudurpark .com.

Prentice, R. C., Witt, S. F., \& Hamer, C. (1993). The experience of industrial heritage: the case of black gold. Built Environment, 19(2), pp. 137-146.
Pujiyati, S., Ridho, A. H., \& Permathasari, A. D. (2017). Statistik objek daya tarik wisata. Jakarta: Badan Pusat Statistik

Raco, J. (2018). Metode penelitian kualitatif: jenis, karakteristik dan keunggulannya. https://doi.org/10. 31219/osf.io/mfzuj

Sedyawati, E., Santiko, H., Djafar, H., Maulana, R., Ramelan, W. D. S., \& Ashari, C. (2013). Candi Indonesia: Seri Jawa: Indonesian-English (Vol. 1). Jakarta: Direktorat Jenderal Kebudayaan.

Sembiring, J. P. (2016). Strategi komunikasi pemasaran objek wisata Gundaling dan pemandian Air Panas Semangat Gunung. Jurnal Simbolika: Research and Learning in Communication Study, 2(1), pp 1-22. https://doi.org/10.31289/simbollika.v2 i1.223

Shereen, M. A., Khan, S., Kazmi, A., Bashir, N., \& Siddique, R. (2020). COVID-19 infection: Origin, transmission, and characteristics of human coronaviruses. Journal of Advanced Research. https://doi.org/ 10.1016/j.jare.2020.03.005

Syamyanti, R. (2018). Pariwisata budaya untuk pelestarian cagar budaya. Diakses pada 10 May 2020, dari https://kebudayaan.kemdikbud.go.id/ bpcbsumbar/pariwisata-budayauntuk-pelestarian-cagar- budaya/

Yulianto, A. (2015). Strategi pemasaran PT. TWC dalam meningkatkan kunjungan wisatawan dan laba usaha pengelolaan candi Borobudur, Prambanan Dan Ratu Boko. Media Wisata, 13(2) pp. 295307 